\title{
GCU
}

Glasgow Caledonian

University

University for the Common Good

\section{Managers as workplace learning facilitators}

Margaryan, Anoush; Milligan, Colin; Littlejohn, Allison

Published in:

International Journal of Human Resources Development and Management

DOI:

10.1504/IJHRDM.2013.055397

Publication date:

2013

Document Version

Author accepted manuscript

Link to publication in ResearchOnline

Citation for published version (Harvard):

Margaryan, A, Milligan, C \& Littlejohn, A 2013, 'Managers as workplace learning facilitators', International Journal of Human Resources Development and Management, vol. 13, no. 2/3, pp. 206-223.

https://doi.org/10.1504/IJHRDM.2013.055397

\section{General rights}

Copyright and moral rights for the publications made accessible in the public portal are retained by the authors and/or other copyright owners and it is a condition of accessing publications that users recognise and abide by the legal requirements associated with these rights.

Take down policy

If you believe that this document breaches copyright please view our takedown policy at https://edshare.gcu.ac.uk/id/eprint/5179 for details of how to contact us. 


\title{
Managers as workplace learning facilitators
}

\author{
Dr. Anoush Margaryan (corresponding author) \\ Senior Lecturer \\ Caledonian Academy, Glasgow Caledonian University \\ 70 Cowcaddens Road, Glasgow G4 0BA, Scotland, UK \\ anoush.margaryan@gcu.ac.uk
}

\author{
Dr. Colin Milligan \\ Research Fellow \\ Caledonian Academy, Glasgow Caledonian University \\ 70 Cowcaddens Road, Glasgow G4 0BA, Scotland, UK \\ colin.milligan@gcu.ac.uk \\ Professor Allison Littlejohn \\ Chair of Learning Technology and Director \\ Caledonian Academy, Glasgow Caledonian University \\ 70 Cowcaddens Road, Glasgow G4 0BA, Scotland, UK \\ Allison.littlejohn@gcu.ac.uk
}

\begin{abstract}
Authors' biographical notes:
Dr. Anoush Margaryan is a Senior Lecturer in the Caledonian Academy, Glasgow Caledonian University. She studies how professionals in knowledge-intensive domains learn and develop their expertise in the context of everyday work and how digital technology can be used to support knowledge work and learning. Anoush has over 70 publications in technology-enhanced professional learning, including a book on workbased learning.
\end{abstract}

Dr. Colin Milligan is a Research Fellow with the Caledonian Academy at Glasgow Caledonian University. He has worked in the area of educational development for around 18 years. His research interests centre on the role of the collective in learning in the workplace, and the role social technologies can play in supporting knowledge workers.

Professor Allison Littlejohn is a Chair of Learning Technology and the Director of the Caledonian Academy at Glasgow Caledonian University. She has almost 20 years' experience leading research and innovation in Technology-Enhanced Learning, working with a wide range of international academic and industry partners, most notably Royal Dutch Shell, for whom she was Senior Researcher 2008-2010. Allison has over 70 academic publications, including two books, and is founding Series Editor for the Routledge Connecting with eLearningbook series. 


\section{Abstract}

This exploratory, interview-based study $(\mathrm{n}=29)$ elicits activities carried out by managers in support of employees' learning and surfaces similarities and differences in the ways these activities are perceived by novice, experienced and mid-career workers. Analysis suggests that managers provide a wide variety of types of learning support, ranging from hands-on support on operational issues, structuring individual development programmes and advice on learning opportunities, to coaching, career advice, counseling and being a role model. The perceptions of novice, experienced and mid-career professionals are compared and contrasted, tentative patterns identified and a typology of managers' learning facilitation activities proposed. The results suggest that to enable managers to facilitate workplace learning effectively, a broader range of competences and skills should be considered when training managers.

Keywords: workplace learning; managers; workplace learning facilitation; managerial facilitation; typology; employee learning

\section{Introduction}

This paper examines what managers do to facilitate workplace learning - that is, learning through and for work (Billett et al, 2008; Eraut, 2004). Workplace learning is a multidisciplinary area involving fields such as learning sciences; adult, vocational and higher education; and organisational, management and labour studies, among others (Tynjala, 2008). Our focus is on understanding workplace learning from an individual rather than organisational perspective - what individuals learn, how they learn, and with whom; what the conditions and practices enhancing workplace learning are; and how workplace learning can be facilitated, by individuals themselves and others in organisations such as trainers, colleagues, managers.

In the workplace, other people - colleagues, managers - are an important source of knowledge and learning support (Doornbos, Bolhuis, and Simons, 2004). The significance of managers in the facilitation of workplace learning has been established (Broad, 1997; Russ-Eft, 2002; Senge, 1990a) and the types of facilitative activities they carry out to support learning have been examined to some extent (Hughes, 2004; De Jong, Leenders, and Thijssen, 1999). However, we have identified three general gaps in the literature. Firstly, research to date has tended to consider managers' facilitative activities at a conceptual level, that is to say what these activities 'should be', rather than what they are in practice (Eraut, 2010; Weaver and Farrell, 1997). Secondly, the limited extant empirical research has examined learning facilitation activities from the perspective of the managers themselves (Ellinger, Watkins, and Barnas, 1999; Powell and Doran, 2003; Wallo, 2008), overlooking supervisees' perceptions of what their managers do in practice to support their learning. Thirdly, research hasn't examined whether or not employees at different experience levels perceive managerial facilitative activities in different ways. Yet whether or not there is such experiencerelated variation in perception is an important empirical question to ask, because the answer could help refine our understanding of how best to support workplace learning, in ways that are tailored to individuals' needs and circumstances. An examination of supervisees' perceptions of managerial facilitative activities, combined with an analysis of the relationship between employees' experience level and their perception of managerial facilitative activities, are relevant vistas for research in workplace learning.

The paper reports findings of an exploratory study that aimed at elucidating employees' perceptions of managerial facilitative activities and examining whether or not there is a variation in perceptions across novice, mid-career and experienced workers. Carried out in a large, multinational company in the energy sector, the study was guided by two research questions:

1. What are the activities that managers carry out to support workplace learning, as perceived by those they supervise?

2. What are the similarities and differences in perceptions of managerial facilitative activities by workers at different stages of experience (novice, experienced and mid-career)? 
This is an Author Accepted Manuscript of the publication: Margaryan, A., Milligan, C., \& Littlejohn, A. (2013). Managers as workplace learning facilitators. International Journal of Human Resource Development and Management 13 (2/3) 206-223

http://www.inderscience.com/offer.php?id=55397

We start by reviewing key findings from relevant previous research. There is limited literature around these two questions, so we use selected studies as examples to provide a wider context in which to contextualise our findings. A systematic literature review is beyond the scope of this paper. Following a brief discussion of the examples of previous research, we explain the methodology, then present and discuss the results of this study. The perceptions of novice, experienced and mid-career professionals in relation to managers' learning support activities are analysed and patterns in responses are identified. We conclude by discussing the limitations of the study, outlining the implications for management learning and by proposing directions for future research.

\section{Literature review}

The concept of facilitative leadership has been advanced over the past decades to signal a departure (at least in rhetoric) from command-and-control management. With the transition to a 'knowledge economy' in the Western world, alternative conceptions of organisations - for example, the idea of a 'learning organisation' (Senge, 1990a) - have become increasingly popular, forcing a reassessment of the responsibilities of managers. Senge (1990b) argued that leaders are responsible for "building organisations where people are continually expanding their capabilities to shape their future - that is leaders are responsible for learning" (p.9). He further stressed: "managers are the only people who can be truly effective in making learning happen" (ibid, p.46). While Senge's argument can be challenged on the grounds that it appears to overlook employees' personal agency in "making learning happen", his point highlights the systemic importance of the facilitative role of managers.

Simultaneously, approaches positing leadership as facilitative have been challenged by proponents of the critical management studies perspective, who argued that leadership is fundamentally impositional and irreconcilable with the personal agency of those who are led (Fryer, 2012). Critical voices included Hughes (2004), who argued that it may be impossible for managers to facilitate learning, due to issues of identity and trust between managers and those being managed. Hughes highlighted a contradiction between the manager's role as an assessor of performance and someone who is required to support learning to improve performance. He maintained that, "organisations that wish to support the facilitation of workplace learning may need to look beyond line management to relatively independent individuals whom staff could realistically come to trust in a facilitative role" (Hughes, 2004, p.286).

What is known from the literature about what managers do to facilitate workplace learning and how this facilitative role is perceived by employees at different experience levels? Ellinger et al (1999) suggested that managers' roles in supporting workplace learning included teaching, coaching, and being educators and facilitators. A detailed taxonomy was developed by Mintzberg (1973), who had proposed 10 roles that managers assume: three interpersonal roles (figurehead, leader, liaison); three informational roles (monitorer [sic], disseminator, spokesperson); and four decision-making roles (entrepreneur, disturbance handler, resource allocator, negotiator). The roles in Mintzberg's taxonomy do not directly focus on the facilitation of learning, although, as some scholars (eg Ellinger et al, 1999) have argued, the informational roles and the decision-making roles are indirectly related to learning. However, both taxonomies are conceptual rather than empirical, and do not distinguish what the facilitator does depending on the level of experience of those whom they facilitate (ie do managers facilitate experienced workers in different ways than they do novices and if so, what are the differences).

An empirically-based taxonomy of managers' facilitative roles was proposed by De Jong et al (1999), whose study surfaced three clusters of roles: the analytic role ("analysing and solving performance problems"); the supportive role ("creating favourable conditions for learning"); and the trainer role ("directly influencing work behaviour") (p.181). However, this taxonomy is limited, having been derived from interviews with human resource development experts, thus representing an 'organisational' view rather than being grounded in individual experiences of those who are being supervised and facilitated. Also, this taxonomy does not distinguish potential experience-related variation in the roles. 
Our literature search produced only two papers that analyse managers' facilitative activities from the perspective of employees. The first was a study by Hirsh et al (2004), examining both supervisees' and managers' views on managerial roles that led to what Hirsh et al called 'good development'. They identified six managerial roles characterised by both managers and supervisees as 'supportive' for learning: setting climate conducive to development; building developmental relationships with their workers; providing frequent, honest and constructive feedback; giving informal coaching; and offering career development opportunities. However, Hirsh et al did not examine potential variations related to supervisees experience level.

The second study is the Learning at Work Survey (LAWS) (Felstead et al., 2004) which explored variations in workers' perceptions of the 'helpfulness' of their line managers in line with workers' position in the organisational hierarchy. Survey respondents were offered a pre-defined set of 'aspects of everyday work' that managers potentially contribute to, such as advising on job improvements, coping with work pressure, and job moves, and were asked to rate the extent of helpfulness of their manager in relation to each of these items. Felstead et al found that employees in lower occupational ranks rated the helpfulness of their managers lower than the employees at higher ranks. However, it remains unclear whether these findings can be extrapolated to demonstrate variation of perceptions of managerial facilitation across experience levels. This is because, firstly, LAWS examined managerial support more broadly, rather than focusing on learning support, and secondly, because one's hierarchical position does not necessarily correlate with one's experience level. A further limitation of LAWS was that it imposed a restricted set of pre-defined roles, rather than scoping in a grounded way the whole spectrum of types of support that managers provide in practice, as perceived by those they supervise.

In summary, there is gap in the literature related to our first research question (What are the activities that managers carry out to support workplace learning, as perceived by those they supervise?) and no literature on our second research question (What are the similarities and differences in perceptions of managerial facilitative activities by workers at different stages of experience (novice, experienced and mid-career)?). We next describe the design of a study devised to address these two questions.

\section{Methodology}

This study was part of a larger research project on how professionals learn in the context of work (Margaryan, Milligan and Littlejohn, 2009). The larger study employed a mixed-methods design, including a quantitative survey $(n=469)$ followed by semi-structured interviews $(n=29)$. In this paper, we report on the findings of the interviews only. We do not report the survey results, because the survey was focused on aspects of workplace learning unrelated to managerial facilitation. We draw on the survey only to identify the experience level of the respondents.

Semi-structured interviews lasting one hour on average were conducted with a group of knowledge workers (engineers, scientists) from a large multinational energy company. Interview respondents were recruited through the above-mentioned survey, at the end of which they where asked to volunteer for follow-up interviews. Twenty-nine respondents volunteered to be interviewed. The interviews took place in November 2008-March 2009.

Interviews were by telephone. At the start of the interview, the respondents were asked to think about their most significant learning experience in the past year - the project or task from which they had learned the most. The interview questions elicited the ways in which respondents set and attained their learning goals to complete the project/task. The interview script is in the Appendix.

During the interview respondents were asked to describe the role other people (in and beyond their workplace) played in supporting their learning. The respondents were free to indicate and discuss anyone who supported them, and were not guided specifically towards considering their managers' role. However, 
This is an Author Accepted Manuscript of the publication: Margaryan, A., Milligan, C., \& Littlejohn, A. (2013). Managers as workplace learning facilitators. International Journal of Human Resource Development and Management 13 (2/3) 206-223

http://www.inderscience.com/offer.php?id=55397

the majority of the respondents (20/29) did talk at length about their line manager. Respondents who mentioned a manager were then prompted to describe the specific ways in which the manager supported them.

Interview data were analysed inductively, using emergent codes. Firstly, all instances of respondents discussing how their managers supported their learning were coded using 'managers' code. Secondly, these particular data on managers were thematically analysed to determine the specific activities that managers carried out. Coding for a sample of data was cross-checked by three researchers to ensure reliability and consistency. Thirdly, the respondents were categorised into three groups according to their experience level, and the identified managerial activities were compared and contrasted across these three groups.

Of the 29 interview respondents, 10 were novices $(\mathrm{N})$, while 12 were experienced $(\mathrm{E})$ and 7 were midcareer employees (MC). We defined 'experienced' as those employees who had 11 and more years of experience and novices as those who had up to 3 years of experience in their discipline at the time of the interview. Those who had 4-10 years of experience were defined as mid-career professionals. There are two reasons for grouping the respondents in this way - a practice-based and a theory-based reason. Firstly, the practice of graduate recruitment and training in this company involves the new recruits undergoing an extensive 'Young Professional' development programme comprised of formal and informal learning opportunities (attendance of in-house courses, coaching and mentoring, job rotation) in the first three years of their employment. Whilst there is a range of learning opportunities available to employees also after the first three years of their employment, the opportunities are less structured or 'programmatic' in nature. We therefore categorised all 'young professionals' as novices. Secondly, research in the field of expertise development suggests that it takes at least a decade of intensive, deliberate practice to achieve superior performance in a domain (Ericsson et al., 2006). We therefore used this 'ten-year rule' as a basis to grouping the experienced employees in our sample.

The interview sample has representation from a range of disciplines, and different job profiles and experience levels. While the sample is diverse, the exploratory nature of the study means that the sample is small. Furthermore, the fact that the respondents were selected on the basis of their interest in the study may have introduced a sampling bias. Driven by pragmatic considerations inevitable when conducting research in real-world business contexts, this sampling strategy did not account for the number of potential participants who may have been omitted from the study. These sampling limitations are common in qualitative research (Daly and Lumley, 2002). The data presented in this paper can only be considered a snapshot of employees' views and may not be representative of the entire worker population of this company. Foregoing these methodological weaknesses, the study offers a valuable contribution to empirical research in this field.

\section{Organisational context}

When studying the facilitation of workplace learning, it is important to considering contextual factors (Ellinger and Cseh, 2007). We therefore discuss some key company-related factors that are important for understanding our results.

First, our focus is on knowledge workers - highly-skilled professionals educated to (post)graduate level whose work primarily comprises knowledge creating, symbolic-analytical activities (Brown, Green and Lauder, 2001; Drucker, 1969; Reich, 1991). Our sample is comprised largely of scientists and engineers.

Second, as with many large multinational companies, the company in which this study was conducted provides extensive learning opportunities to its employees. Staff can make use of opportunities that are both internal (provided through the corporate open university or learning centers) and external (conference and workshop attendance, enrollment in external educational and training programmes). A loose structure 
This is an Author Accepted Manuscript of the publication: Margaryan, A., Milligan, C., \& Littlejohn, A. (2013). Managers as workplace learning facilitators. International Journal of Human Resource Development and Management 13 (2/3) 206-223

http://www.inderscience.com/offer.php?id=55397

is fine-tuned to take advantage of both programmed and emerging opportunities for learning. Learning provision generally consists of a variety of courses (online, blended and classroom-based) focused on core technical and commercial topics. Courses are supplemented by a range of on-the-job learning options, such as coaching, mentoring and job rotation. In this company, coaching and mentoring are distinct roles, which are either formally assigned to or taken on informally by individuals. While there are a wide range of definitions of coaching/mentoring (Ellinger et al, 2011), in this company coaching is defined as a taskfocused relationship, helping individuals to do their current job better, while mentoring is seen as a longterm relationship, aimed at helping individuals develop their career.

Third, a key mechanism to support learning in this organisation is Individual Development Planning (IDP), a process closely linked with annual performance appraisal. These two organisational processes together support individuals in planning of work goals and tasks, identification of learning needs and formulation of learning goals to help them achieve their short-term work goals and long-term career aspirations. IDP results in concrete actions for addressing learning goals. For example, IDP could include participation in courses; coaching and mentoring; or conference attendance. IDP is developed and regularly reviewed by the employee in collaboration with their line manager. Together with the annual performance appraisal, IDP provides individuals with a structured set of reflection points throughout a year, some planned and others ad-hoc.

\section{Results and discussion}

Interviewees were asked to indicate other people within or outside the company who were key to their learning. Eight categories of 'significant others' emerged, with line managers as the most frequently mentioned category, representing the most significant role for all three groups, although team members and colleagues in other parts of the organisation were also a very significant category (Table 1). Line managers were mentioned more frequently by novices $(80 \%)$ than by experienced $(58 \%)$ or mid-career professionals $(71 \%)$.

Table 1. 'Significant others' in the workplace

\begin{tabular}{|l|c|c|c|c|}
\hline 'Significant other' & $\begin{array}{c}\text { No of respondents } \\
\text { who mentioned the } \\
\text { category }\end{array}$ & Novices & Experienced & Midcareer \\
\hline Line Manager & $20 / 29$ & $8 / 10$ & $7 / 12$ & $5 / 7$ \\
\hline Team members & $19 / 29$ & $8 / 10$ & $6 / 12$ & $5 / 7$ \\
\hline $\begin{array}{l}\text { Colleagues elsewhere in } \\
\text { organisation }\end{array}$ & $16 / 29$ & $7 / 10$ & $5 / 12$ & $4 / 7$ \\
\hline Mentor & $10 / 29$ & $4 / 10$ & $3 / 12$ & $3 / 7$ \\
\hline Coach & $7 / 29$ & $3 / 10$ & $2 / 12$ & $2 / 7$ \\
\hline $\begin{array}{l}\text { Externals (university } \\
\text { professor, friend, partner, } \\
\text { supplier) }\end{array}$ & $4 / 29$ & $3 / 10$ & $1 / 12$ & $0 / 7$ \\
\hline $\begin{array}{l}\text { Senior leaders } \\
\text { HR staff }\end{array}$ & $2 / 29$ & $0 / 10$ & & \\
\hline
\end{tabular}

The importance of managers in the learning processes is in line with the literature and is also likely to have been influenced by the nature of organisational learning management processes (IDP and performance appraisal), which in this company involve line managers to a significant extent. The data analysis revealed the following range of facilitative activities by managers: 
This is an Author Accepted Manuscript of the publication: Margaryan, A., Milligan, C., \& Littlejohn, A. (2013). Managers as workplace learning facilitators. International Journal of Human Resource Development and Management 13 (2/3) 206-223

http://www.inderscience.com/offer.php?id=55397

- seven activities identified by novices: structuring individual development plan; regular assessment of performance and progress towards learning goals; advice on learning opportunities; coaching; handson support with operational tasks; counselling; being a role model;

- five activities identified by experienced workers: advice on individual development plan; career development guidance; advice on learning opportunities; coaching; advice on operational tasks; and

- four activities identified by mid-career professionals: structuring individual development plan; career development guidance; advice on learning opportunities; coaching.

These activities are detailed, the differences between them are described and perceptions of novice, experienced and mid-career respondents are presented and discussed next.

\section{Novices' perceptions of managers' facilitative activities}

Of the 20/29 respondents who identified their manager as a key person who supported their learning, eight were novices, representing $80 \%$ of all the novices who participated in the interviews. Analysis of the interview data surfaced seven facilitative activities carried out by managers:

1. Structuring individual development plan. A key facilitative activity of the line manager is supporting novices in planning and structuring their personal development, largely through the IDP process discussed in Section 4. One novice explained:

"My Line Manger purposely discuses with me... when I should do this training course or what kind of other projects should I do to develop my other competencies in this kind of area. That is very much part of my Individual Development Plan." (N1)

2. Regular assessment of performance and progress towards learning goals. Line Managers also provide novices with regular, feedback about their performance and discuss their progress in their personal development programme. This is carried out both formally, as part of the IDP process, and informally:

"My Manager and I meet on a regular basis to discuss basically my learning throughout the week, month to month, that kind of thing and what I can improve on and what I am doing well and what not. My Manger is very good at communicating those things to me, but I don't follow any formal process. And some of the time he asks me what kind of courses I want to take and that, to progress my career level." (N4)

3. Advice on learning opportunities. Novices indicated that managers regularly and actively directed them to a range of different learning opportunities, both formal and informal, ensuring that these were tailored to novices' learning needs:

"My Line Manager covers what kind of courses do I need and what would be appropriate at what time, [involvement in] what kind of projects would help me, stuff like that are done by my Line Manager.... He explains to me why we do different things and how we approach people, and kind of tries to fit pieces together because I don't see the full picture all the time." (N2).

Line managers' advice is not only through organisational processes such as IDP. Managers provide informal advice on learning opportunities on a day-to-day basis:

"For example, [I went on] a training course for Finance for non-finance people, and she found out that this course was available and so she just forwarded an email and said 'well, you have expressed interest in this before, so here is a training course that you can take online'. So it is both formal and kind of informal, on a day-to-day basis, whenever she gets information." (N1). 
This is an Author Accepted Manuscript of the publication: Margaryan, A., Milligan, C., \& Littlejohn, A. (2013). Managers as workplace learning facilitators. International Journal of Human Resource Development and Management 13 (2/3) 206-223

http://www.inderscience.com/offer.php?id=55397

4. Coaching. Novices indicated that their line managers often acted as formal coaches, in addition to the other types of formal and informal advice and support they provided.

"There is somebody that is identified and my mentor and there is another guy that is identified as my coach. The coach is, he is my direct supervisor. With the coach it is a day-to-day interaction, with the mentor we plan for it sort of monthly where we sit down..." (N7)

5. Hands-on support with operational tasks. Novices also indicated that they turned to their Line Manager as a first-line contact when faced with operational or technical issues. This support is often on an informal, ad-hoc basis:

"I have always sort of worked out a way, chatted around with the Manager and got into sort of an agreement, he may find me knocking on the door everyday..." (N7)

"I had a fantastic Manger who wasn't holding my hand, but it was more that I would do work and check with him and then he would go to the senior people with it..." (N8)

6. Counselling. Managers also acted as counsellors when employees find themselves in stressful situations. While counselling may be a part of what a coach or a mentor does, in our data it emerged as a distinct activity type, in that counselling was carried out by managers who weren't at the same time a coach or a mentor to the employees who discussed counselling in the interviews:

"It was quite crazy because we had just settled down on a big project and she had managed things before, so I think she could see what was going on with me and she was able to explain things to me... because I was getting a little worried... it is very hard adjusting." (N8)

7. Being a role model. Finally, novices indicated that line managers serve as role models, from whom they learned vicariously:

"I have good Managers and bad Managers and you learn from them, see what they do and what they don't do." (N8)

"His style was very different from my style but I learned a lot from him as a good Manager and I think that was probably how I learned to manage my team when I finally did. He was always very, very professional which was something I appreciated. So I learned from him, definitely, seeing how he did it. But he never explained to me that he did it. I just saw it." (N3).

\section{Experienced employees' perceptions of managers' facilitative activities}

Seven experienced professionals (representing 58\% of the expert population in the sample) highlighted their line manager as a key workplace 'significant other'. The analysis of their accounts resulted in the following five learning facilitation activities:

1. Advice on individual development plan. Analogous to novices, experienced staff indicated that line managers contributed to their personal development planning. However, for experienced professionals this type of support seems to be more 'advisory', and less directive, than for novices. This point is illustrated in a commentary by two senior professionals:

"I have my personal goals and on a regular basis they are discussed with my line manager. Now, periodically he will remind me, or actually I will remind him, that we need to update my goals. It is very open and also it is very, kind of, led by the individual." (E10) 
This is an Author Accepted Manuscript of the publication: Margaryan, A., Milligan, C., \& Littlejohn, A. (2013). Managers as workplace learning facilitators. International Journal of Human Resource Development and Management 13 (2/3) 206-223

http://www.inderscience.com/offer.php?id=55397

"Because I am a $<$ senior $>$ job group within $<$ company $>\ldots$ it is not mandatory for us to do the Individual Development Plan. So I do an informal one with my boss. Mainly we found out now that I am trying to develop my skills in Project Management, I have identified that is one of the things that I would really like to do." (E9).

2. Career development guidance. Managerial facilitation of novices' learning aims largely at helping novices devise and structure their learning goals and development programmes, aiming to bring them up to speed quickly. By contrast, line managers' support to experienced workers tends to focus on longer-term career development advice:

"Your Line Manager also knows what is going within the organisation, what future plans will look like and which opportunities might come up. And he knows his staff. And based on that knowledge, [he] will discuss with me, for instance after opening my window and the next opportunity, what use that could be, based on an open conversation, on the view of your Line Manager, as well as your wishes. That is pretty open and transparent, you always can have such a discussion with your Line Manager. Your Line Manager is with you in making that next step in the career." (E6).

By 'opening the window' this respondent is referring to a practice within this organisation that encourages employees to switch roles every 4-5 years. Employees are encouraged to move to another part of the company to gain a deeper understanding of the different domains and cultures across the company and to ensure effective flow of knowledge and expertise within the company.

3. Advice on learning opportunities. Similar to novices, experienced staff indicated that line managers regularly informed them of courses and other learning opportunities and encouraged them to make use of these opportunities. There was no variation in the accounts of novice and experienced professionals in relation to the forms of career advice.

"...my current role... is overall new to me so I have to improve my knowledge of a number of fields in contracting that is the one aim and my boss of course he says you go out there and fine, even on the internet he says and a number of courses you can follow, it is there and do it." (E3)

4. Coaching. Managers also formally act as coaches and mentors to experienced staff:

"We are not too bad in that perspective. I am fortunate, in that my current boss has a lot of experience in this area, she worked as a professional coach. She is quite diligent in giving us some coaching and mentoring, so we are quite fortunate." (E1).

5. Advice on operational tasks. Similar to novices, experienced workers also indicated that their Line Manager was the 'first port of call' when faced with an operational problem or a new task:

"I would go to somebody within the organisation that I think might have the answer. I would start with my boss." (E7)

\section{Midcareer employees' perceptions of managers' facilitative activities}

$71 \%$ of midcareer respondents (5/7) viewed their manager as a key contributor to their learning and work. Four types of facilitative activities emerged from the analysis of their interview data. Some mid-career professionals accounts of managers' facilitative activities were akin to those of novices, whilst others were similar to experienced employees.

1. Structuring individual development plan. Mid-career professionals' accounts of this facilitative activity were very similar to those of novices. The data suggests midcareer professionals' perceptions may have more in common with novices' than with experienced staff's views on the nature of input that their line 
This is an Author Accepted Manuscript of the publication: Margaryan, A., Milligan, C., \& Littlejohn, A. (2013). Managers as workplace learning facilitators. International Journal of Human Resource Development and Management 13 (2/3) 206-223

http://www.inderscience.com/offer.php?id=55397

managers provide into their individual learning programme.

2. Career development guidance. Descriptions and characterisations of this activity by mid-career professionals were similar to those of experienced staff. However, from the analysis, mid-career professionals were more concerned about their understanding of the career development opportunities open to them within the company than experienced employees were. They were particularly concerned with the way in which the company viewed their potential for career progression, in particular how line managers communicated these organisational intentions to employees. While describing his line managers' role in planning his career progression, a mid-career respondent remarked:

"It is rather difficult to say if there is an opportunity for you to go further or not. You don't know the plans of your bosses, whether they can see for you to be good for some supervisory position or not. Even if they do, they do not share this knowledge with you. So you do not know what you should be prepared for. You do not plan your career like in the case that, okay they say 'we are looking at you as a manager for this or that department in the near future, please get prepared'." (MC1)

3. Advice on learning opportunities. Mid-career respondents' perceptions of this facilitative activity were qualitatively similar to those of novices and experienced staff.

4. Coaching. Mid-career respondents, like novices and experienced worker, identified coaching as a key activity of their managers in supporting their learning. However, mid-career professional respondents were more cautious than novices and experienced workers were about the effectiveness and usefulness of a coaching relationship with their manager.

"I mean with my supervisor, some topics, it could be you don't want to say anything or that person could have targets in their head when they talk to you and they push you in a certain direction. I think with someone who is outside that business environment, but who is still batting for the same company, they can be objective when they coach you." (MC3)

On the basis of the interview results, an initial typology of managers' activities in the facilitation of workplace learning is proposed (Table 2). Activities mentioned exclusively by a specific grouping of respondents are highlighted in bold.

Table 2. A typology of managers' activities in the facilitation of workplace learning

\begin{tabular}{|l|l|l|}
\hline \multicolumn{1}{|c|}{ NOVICES } & \multicolumn{1}{|c|}{ EXPERIENCED } & \multicolumn{1}{|c|}{ MID-CAREER } \\
\hline $\begin{array}{l}\text { Structuring individual } \\
\text { development plan }\end{array}$ & $\begin{array}{l}\text { Advice on individual } \\
\text { development plan } \\
\text { Regular assessment of } \\
\text { performance \& progress towards } \\
\text { learning goals }\end{array}$ & $\begin{array}{l}\text { Structuring individual } \\
\text { development plan }\end{array}$ \\
\hline Advice on learning opportunities & Advice on learning opportunities & Advice on learning opportunities \\
\hline $\begin{array}{l}\text { Coaching } \\
\text { Hands-on support with } \\
\text { operational tasks }\end{array}$ & Career development guidance & Career development guidance \\
\hline Counselling & Advice on operational tasks & Coaching \\
\hline Being a role model & & \\
\hline
\end{tabular}

P10 green archived author postprint after 6-mth embargo (see last page for details). Please download from the publisher if possible. 
In summary, the findings indicate that managers provide a wide variety of types of learning support, ranging from counselling and being a role model to hands-on support with operational tasks, coaching and career advice to structuring and monitoring individuals' personal development planning and performance. Some of these facilitative activities have been part of existing typologies, in particular activities related to offering feedback, coaching and career development advice in Hirsch et al's typology (2004) along with limited aspects of informational and decision-making roles in Mintzberg's account (1990). In contrast to Hughes' findings (2004), managers in our study had a very close involvement in the facilitation of their supervisees' learning, and managers' involvement was viewed largely positively and, indeed, expected by the respondents, possibly reflecting the organisational context and learning support processes in this company. Our findings, therefore, provide empirical evidence for the actuality of workplace learning facilitation by managers. We do not claim that such facilitative approaches are characteristic of other types of organisations, or even of other types of workplaces within this particular organisation.

The types of support line managers provide appear to be broadly similar across the three groups, but there are also differences. In particular, some managerial facilitative activities- counselling, being a role model, hands-on support with work tasks, and regular assessment of progress towards learning goals - were mentioned exclusively by novices. In addition, managers' supportive activities directed at novices appear to focus on short-term issues, shifting to longer-term issues when dealing with experienced workers. Where personal development planning is concerned, managers' input into structuring or monitoring experienced professionals' learning is more advisory rather than hands-on. In the case of mid-career workers, some types of learning support provided by managers are similar to those that novices receive, whilst others are more aligned with those that experienced workers are provided with. In contrast to novices and experienced employees, midcareer professionals appear to be more critical of the effectiveness and usefulness of some managerial facilitative activities, in particular those related to coaching and career advice.

Managerial activities described in this paper are largely indicative of a consensus-oriented rather than a more conventional, transactional leadership style (Bass, 1998). In interpreting these findings, it is important to keep in mind the knowledge work context of this study, which could have influenced the outcomes. Knowledge workers tend to be autonomous, in particular in setting the detailed processes they follow in doing their work, the circumstances in which they think best, and the schedules and locations in which they do their work (Davenport, 2005). This autonomy is an inherent attribute of the nature of these professionals' work, often premised on personal expertise and discretion. And because knowledge workers own their means of production (their knowledge) it is difficult for organisations to deny them this autonomy. Also, the outputs of knowledge work are difficult to specify in great detail, therefore knowledge work contexts tend to be characterised by relatively limited reliance on rules and prescribed procedures. Consequently, a transactional leadership style tends to be less effective when applied to these professionals, necessitating the adoption of more consensus-based and participatory management approaches. This personal autonomy extends to the domain of learning: knowledge workers tend to take more responsibility for their own learning as they manage their work and professional development day-today. Therefore, when a knowledge worker draws on their manager to help with learning, this help tends to be less directive than in other contexts.

\section{Conclusions}

This exploratory study sought to identify and systematise the types of workplace learning facilitation that managers provide, as perceived by those they supervise. The study also aimed to begin to elucidate similarities and differences in how different types of employees perceive their managers, focusing on novice, experienced and mid-career professionals. Whilst exploratory, this study contributes to the literature by suggesting possibilities for extending the existing typologies, both in terms of the activities being surfaced and perspectives of different types of employees taken into account. The study uncovered a wide range of managerial facilitative activities. From the novice workers' 
This is an Author Accepted Manuscript of the publication: Margaryan, A., Milligan, C., \& Littlejohn, A. (2013). Managers as workplace learning facilitators. International Journal of Human Resource Development and Management 13 (2/3) 206-223

http://www.inderscience.com/offer.php?id=55397

perspective, these activities include: structuring individual development programme; regular assessment of performance and feedback on progress towards learning goals; advice on learning opportunities; coaching; hands-on support with operational tasks; counselling; and being a role model. From experienced employees' point of view, the managers' facilitative activities include: advice on individual development planning; career development advice; advice on learning opportunities; coaching and mentoring; and operational advice. Mid-career professionals identify the following key activities of line managers in supporting workplace learning: advice on career development opportunities; advice on learning opportunities; coaching; and structuring personal development programme. We uncovered indicative differences in the perceptions of managers' facilitative activities across these three groups. However, since this study was exploratory we put forward these findings as a tentative first step towards identifying the various activities of line managers in facilitating learning at work from a supervisee perspective.

A key limitation of our study is the small sample size across the three sub-groups. Also the methodology was limited to a semi-structured, retrospective interview. While the methodology was appropriate for the overarching research goals (an introspective account of individual perceptions) we acknowledge the problems associated with the use of interviews. Previous research has suggested that individuals' retrospective judgments may be inaccurate (Townsend and Heit, 2011). Retrospective methods based on self-reported data (such as interviews) alone are likely to expose only the surface features rather than reliably revealing the past experiences.

Further research could use in-depth ethnographic approaches or real-time studies (such as talk-aloud protocols in the context of an authentic task) and focus on a larger group of participants, to identify more robust patterns and to generate a more accurate typology. Future research could bring together findings from studies examining learning facilitation activities as perceived by supervisees with perceptions of managers and comparing and contrasting these perceptions. This would provide insight into potential tensions and individual and organisational contradictions around learning relationships in the workplace. It would also be useful to examine whether or not there is variation in the perceptions of those supervisees who have managerial responsibilities and those who do not. Another useful avenue of future research could include an examination of the specific activities that other categories of 'significant others', in particular team members and colleagues elsewhere in the organisation (in our study, the second and third most frequently mentioned category of 'significant others' respectively) carry out, comparing and contrasting the nature and outcomes of their facilitative activities with those of managers.

Notwithstanding the need for more research, this study offers useful insights for the practice of workplace learning and management learning in particular. Key questions for organisations are: Are managers sufficiently well prepared for the wide range of learning support activities they carry out? Do managers have the necessary specialist skills such as counselling and coaching to accomplish these activities well? Preparation for managerial roles must be given a higher priority in orgainsations, and take into consideration broader types of competences and skills to enable managers to facilitate workplace learning effectively.

\section{Acknowledgements:}

The authors would like to thank Karen Smith (University of Greenwich, UK) and Dane Lukic (Glasgow Caledonian University, UK) for their help in collecting and coding the interview data. We are grateful to the participants and our industrial partners for their time, insights and stimulating collaboration.

\section{References}

Bass, B.M. (1998) Transformational Leadership: Industrial, Military, and Educational Impact. Lawrence Erlbaum Associates, Mahwah, NJ.

Billett, S., Harteis, C. and Etelaepelto, C. (Eds.), (2008) Emerging Perspectives of Workplace Learning, Sense Publishers, Rotterdam/Taipei.

Broad, M. (1997) Transferring Learning to the Workplace, ASTD, Alexandria, VA. 
This is an Author Accepted Manuscript of the publication: Margaryan, A., Milligan, C., \& Littlejohn, A. (2013). Managers as workplace learning facilitators. International Journal of Human Resource Development and Management 13 (2/3) 206-223

http://www.inderscience.com/offer.php?id=55397

Brown, P., Green, A. and Lauder, H. (2001) High Skills: Globalisation, Competitiveness and Skill Formation, Oxford University Press, Oxford.

Daly, J. and Lumley, J. (2002) 'Bias in qualitative research designs', Australian and New Zealand Journal of Public Health, Vol. 26 No.4, pp.299-300.

Davenport, T. (2005) Thinking for a Living: How to Get Better Performance and Results from Knowledge Workers, Harvard Business School Press, Boston, MA.

De Jong, J., Leenders, F. and Thijssen, J. (1999) 'HRD tasks of first-level managers', Journal of Workplace Learning, Vol. 11 No.5, pp.176-183.

Doornbos, A., Bolhuis, S. and Simons, R.J. (2004) 'Modeling work-related learning on the basis of intentionality and developmental relatedness: a noneducational perspective', Human Resource Development Review, Vol. 3 No.3, pp.250-274.

Drucker, P. (1969) The Age of Discontinuity, Harper \& Row, New York.

Ellinger, A., Hamlin, R., Beattie, R., Wang, Y-L. and McVicar, O. (2011). 'Managerial coaching as a workplace learning strategy', In Poell, R. and van Woerkom, M. (Eds.), Supporting Workplace Learning, Springer, Dordrecht, pp.71-87.

Ellinger, A. and Cseh, M. (2007) 'Contextual factors influencing the facilitation of others' learning through everyday work experiences', Journal of Workplace Learning, Vol. 19 No. 7, pp.435-452.

Ellinger, A, Watkins, K. and Barnas, C. (1999) 'Responding to new roles: a qualitative study of managers as instructors', Management Learning, Vol. 30 No. 4, pp.387-412.

Eraut, M. (2004) 'Informal learning in the workplace', Studies in Continuous Education, Vol. 26 No. 2 , pp.247-273.

Eraut, M. (2010) 'Knowledge, working practices and learning', in Billet, S. (Ed.), Learning through Practice: Models, Traditions, Orientations and Approaches, Springer, Dordrecht, pp.37-58.

Ericsson, K.A., Charness, N., Feltovich, P.J. and Hoffman, R.R. (Eds.) (2006) The Cambridge Handbook of Expertise and Expert Performance, Cambridge University Press, Cambridge, USA.

Felstead, A., Fuller, A., Unwin, L., Ashton, D., Butler, P., Lee, T. and Walters, S. (2004) 'Exposing learning at work: results from a recent survey'. Paper Presented at Work, Employment and Society Conference. 1-3 September, 2004. UMIST, UK. [online] http://citeseerx.ist.psu.edu/viewdoc/summary?doi=10.1.1.197.2827 (Accessed 17 January 2012).

Fryer, M. (2012) 'Facilitative leadership: drawing on Jürgen Habermas' model of ideal speech to propose a less impositional way to lead', Organization, Vol. 19 No.1, pp.25-43.

Hirsh, W., Silverman, M., Tamkin, P. and Jackson, C. (2004) Managers as developers of others, Institute for Employment Studies, UK, Report 407.

Hughes, C. (2004) 'The supervisor's influence on workplace learning', Studies in Continuing Education, Vol. 26 No.2, pp.275-287.

Hughes, C. (2002) 'Issues in supervisory facilitation', Studies in Continuing Education, Vol. 24 No.1, pp.57-71.

Margaryan, A., Milligan, C., \& Littlejohn, A. (2009). Self-regulated learning and knowledge sharing in the workplace: Differences and similarities between experts and novices. In Proceedings of the 2009 Researching Work and Learning (RWL) Conference, Roskilde, Denmark.

Mintzberg, H. (1973) The Nature of Managerial Work, Harper \& Row, New York.

Powell, T. and Doran, M. (2003) 'Managers' perceptions of their role in facilitating employee learning', in Lynham, S. and Egan, T. (Eds.), Proceedings of the Academy of Human Resources Development (AHRD) Conference, Bowling Green, OH, USA, pp. 366-373.

Reich, R. (1991) The Wealth of Nations, Simon \& Schuster, London.

Russ-Eft, D. (2002) 'A typology of training design and work environment factors affecting workplace learning and transfer', Human Resources Development Review, Vol. 1 No.1, pp.45-65.

Senge, P. (1990a) 'The Leader's new work: Building learning organisations', Sloan Management Review, Vol. 32 No.1, pp.7-23.

Senge, P. (1990b) The Fifth Discipline, Doubleday, New York.

Townsend, C and Heit, E. (2011) 'Judgements of learning and improvement', Memory \& Cognition, Vol. 39 No. 2, pp.204-216. 
This is an Author Accepted Manuscript of the publication: Margaryan, A., Milligan, C., \& Littlejohn, A. (2013). Managers as workplace learning facilitators. International Journal of Human Resource Development and Management 13 (2/3) 206-223

http://www.inderscience.com/offer.php?id=55397

Tynjala, P. (2008) Perspectives into learning in the workplace, Educational Research Review, Vol. 3, pp.130-154.

Wallo, A. (2008) The leader as a facilitator of learning at work: A study of learning-oriented leadership in two industrial firms, Linköping Studies in Behavioural Science, No 137, University of Linköping.

Weaver, R.G. and Farrell, J.D. (1997) Managers as Facilitators, Berrett-Koehler Publishers, San Francisco.

\section{Appendix. Interview Script}

Name: XXXXXXXXXX

Phone Number: XXXXXXXXX

Interview Date/Time: $\mathrm{XXXXXXXXX}$

Audio file name: XXXXXXXX.mp3

\section{INTRODUCTION}

Introduce myself and thank him/her for his/her time. Indicate that we expect to spend up to 1 hour.

\section{FORMAT AND PURPOSE OF INTERVIEW}

For this interview, we have prepared a series of questions, designed to build on the online survey, which you completed. This interview will focus on the learning and development you undertake to help you carry out your job.

\section{CONFIRM HOW INFORMATION WILL BE RECORDED AND USED}

The interview will be recorded. The information you provide will be anonymised before anything is used in any final report.

If there is anything particularly unusual about the interviewees responses to the online survey they could be asked to elaborate here. But the default would be that there are no questions about the online survey. Prior to each interview, the interviewer, or a member of the project team will have gone through and made a very brief note of the key features of the interviewee and any interesting responses they provided.

Summary of Interview

The interview is semi-structured - which means we have around 5 major questions, and within those I have a number of other prompt-questions that I will ask to focus your answers on the information we are seeking.

I would like to ask you some specific questions about your role and your learning and development in the context of your work. For the purposes of our research, we consider learning and development to include activities ranging from formal courses and coaching/mentoring arrangements through to informal activities such as participation in professional communities to top-up professional knowledge in your field and networking with your peers.

Please describe your role.

(This question can be viewed as an icebreaker, providing general background information, which you are likely to refer to in the remainder of the interview. You may wish to probe to try and make sure the following is captured)

- Seniority/expertise 
- Typical tasks (the language they use may indicate the complexity of the task - process, project, job, ... do they give an indication of whether they perform tasks serially, or in parallel)

- Team structure the person operates within (note that this will complement information we already have (on autonomy, collaboration, formalness of teams, team size etc) so we need not go into much detail.

- An insight into how the individual manages the competing activities which constitute their job Focusing on the task or project from which you have learned most in the last year and talk about what and how you learned?

(You may wish to probe to try and make sure the following is captured)

- What did they learn

- How did they learn

- Who did they learn from/with?

- Why was it valuable (can it be reused etc.)

- Phases of work (related to the granularity of tasks they perform, but likely to include (or not) planning, execution and reflection)

In more general terms, what are the main ways that you feel you learn and develop? Again, consider both formal and informal learning opportunities and activities.

(You may wish to probe to try and make sure the following is captured)

- People (are other people within your organisation key to your learning and development)

- Events/Experiences (do you associate learning with specific phases of your work, milestones in projects etc.)

- Resources (do you feel that resources - books, digital content etc. play an important role in your learning and development, and if so, how? Do you set aside time each day/week to keep up to date with developments in your field)

- Tools (are there any tools which help you in this process, for instance do you keep a journal,

- Reflection (do you feel you actively reflect on your work and how you might learn from your experience) - note that some respondents may mention the project after-action reviews; when they do probe for learning \& development-specific outcomes of this process for the individual

(You may also build on this question to ask about 'approaches to learning and development, to what extent they relate it to formal career/development processes such $X X X X X X X X X X X X X X X X X$. Here, there may be differences between how novices and experts approach their $L \& D)$.

Which groupings within the organisation do you identify with, and how do you interact with these groupings?

(Probe to see whether the respondent makes a distinction between people they work with and people they learn from)? Also, do they identify with others in project teams or others with similar skills/backgrounds? With regard to project teams, do they develop relationships by working with the same people on different projects?

Is there anything that you would like to change in the way you currently operate to improve your learning and development?

(Probe to identify barriers and enablers, is there anything they consider special about their particular context? Help them to focus on their learning and development)

That's great, thanks very much for taking the time to talk with me and for your contribution to our study, it's much appreciated.

Our final report is given provided to $\mathrm{XXXXX}$, however if you wish, we can request that it be sent to respondents. Would you like to see a copy of the report? 
This is an Author Accepted Manuscript of the publication: Margaryan, A., Milligan, C., \& Littlejohn, A. (2013). Managers as workplace learning facilitators. International Journal of Human Resource Development and Management 13 (2/3) 206-223

http://www.inderscience.com/offer.php?id=55397

\section{GOODBYE}


This is an Author Accepted Manuscript of the publication: Margaryan, A., Milligan, C., \& Littlejohn, A. (2013). Managers as workplace learning facilitators. International Journal of Human Resource Development and Management 13 (2/3) 206-223

http://www.inderscience.com/offer.php?id=55397

\section{Journal: International Journal of Human Resources Development and} Management (ISSN: 1465-6612, ESSN: 1741-5160)

RoMEO: This is a RoMEO yellow journal

Paid OA: A paid open access option is available for this journal.

\section{Author's Pre-} print:

$$
\text { author can archive pre-print (ie pre-refereeing) }
$$

Author's Postprint:

subject to Restrictions below, author can archive post-print (ie final draft postrefereeing)

Restrictions:

- 6 months embargo

Publisher's Version/PDF: subject to Restrictions below, author can archive publisher's version/PDF

Restrictions:

- 6 months embargo

General Conditions:

- Cannot archive until publication

- Author's pre-print and Author's post-print on author's personal website, institutional repository or subject repository

- Publisher copyright and source must be acknowledged

- Must link to journal webpage and /or DOI

- Publisher's version/PDF cannot be used, unless covered by funding agency rules

- Authors covered by funding agency rules, may post the Publisher's Version/PDF in subject repositories after a 6 months embargo

Mandated OA: (Awaiting information)

Paid Open Author Open Access

Access:

Notes: - Reviewed 10/02/2014

- Author's post-print equates to Inderscience's Proof

Copyright: post-print policy - Authors Agreement (pdf)

Updated: 25-Jun-2014 - Suggest an update for this record

Link to this http://www.sherpa.ac.uk/romeo/issn/1465-6612/ page:

Published by: Inderscience - Yellow Policies in ROMEO

This summary is for the journal's default policies, and changes or exceptions can often be negotiated by authors.

All information is correct to the best of our knowledge but should not be relied upon for legal advice. 